\title{
Violence in Intimate Relationship between Same-Sex Partners: Prevalence Study
}

\author{
Ana Maria R. Santos \\ Sónia Maria Martins Caridade ${ }^{1}$ \\ Faculdade de Ciências Humanas e Sociais, Universidade Fernando Pessoa, Porto, Portugal
}

\begin{abstract}
This study aimed to characterize the prevalence of violence in intimate relationships between same-sex partners in Portugal using the Revised Conflict Tactics Scales. The study included 168 participants, mainly women (76.2\%), who were between 18 and 35 years of age with an average age of 22.5 (SD $=3.79)$. In terms of perpetration, the results showed higher rates for psychological aggression $(70.2 \%$ mild and $29.8 \%$ severe), physical abuse that leaves no sequelae (26.8\% mild and $9.5 \%$ severe) and mild sexual coercion (28\%).Regarding victimization, a high rate of minor psychological aggression $(69.2 \%)$ was also found. The men admitted to adopting more behaviours related to both minor and severe sexual coercion. A positive and significant relationship was found between the duration of an intimate relationship and victimization by minor psychological aggression. These results suggest the need to develop specific support interventions for different types of victims, as well as the need to implement more prevention efforts tailored to different situations.
\end{abstract}

Keywords: Violence, intimate relationships, same-sex partners, prevalence.

\section{Violência nas Relações Íntimas entre Parceiros do Mesmo Sexo: Estudo de Prevalência}

\section{Resumo}

Este estudo procurou caracterizar a prevalência da violência nas relações íntimas entre parceiros do mesmo sexo em Portugal, recorrendo às Escalas de Táticas de Conflito Revisadas. Participaram neste estudo 168 participantes, com idades compreendidas entre os 18 e os 35 anos, cuja média de idade foi de 22,5 anos $(D P=3,79)$, sendo a maioria do sexo feminino $(76,2 \%)$. Em termos de perpetração, os resultados revelaram uma elevação da agressão psicológica (70,2\% na ligeira e 29,8\% na severa); uma ligeira elevação dos atos que não deixam sequelas (26,8\% no ligeiro e $9,5 \%$ no severo) e, ainda, uma preponderância da coerção sexual ligeira (28\%). Em relação a vitimação, constatou-se igualmente uma preponderância da agressão psicológica ligeira $(69,2 \%)$. Os homens admitiram adotar mais comportamentos de coerção sexual, tanto na forma ligeira como severa. Foi ainda possível apurar a existência de uma relação positiva e significativa entre a duração do relacionamento íntimo e a vitimação por agressão psicológica ligeira. Estes resultados apelam à elaboração de respostas de apoio específicas para os diferentes tipos de vítimas, bem como a aposta na implementação de esforços preventivos mais contextualizados às diferentes realidades.

Palavras-chave: Violência, relações íntimas, parceiros do mesmo sexo, prevalência.

Mailing address: Universidade Fernando Pessoa, Faculdade de Ciências Humanas e Sociais, Praça 9 de Abril, 349, Porto, Portugal 4249-004. Fone: +351225071300 Fax: +351225508269. E-mail: soniac@ufp.edu.pt 


\section{La Violência en las Relaciones Íntimas de Personas del Mismo Sexo: Estudio de Prevalencia}

\section{Resumen}

Este estudio trata de caracterizar la prevalencia de la violencia en las relaciones íntimas entre parejas del mismo sexo en Portugal, utilizando la Escala Táctica de Conflictos Revisada. El estudio incluyó 168 participantes, de edades comprendidas entre los 18 y 35 años, cuya edad media fue de $22.5(D E=3.79)$, la mayoría de los cuales eran mujeres $(76.2 \%)$. En cuanto a la agresión, los resultados mostraron un aumento en la agresión psicológica (70.2\% en agresiones leves y graves en el $29.8 \%$ ); un ligero aumento de los actos que no dejan secuelas (26.8\% leves y $9.5 \%$ graves) y también un ligero predominio de la coacción sexual (28\%). En el nivel de victimización, también se encontró una ligera preponderancia de la agresión psicológica (69.2\%). Los hombres admitieron que realizan más conductas de coacción sexual, tanto en forma leve y grave. También fue posible determinar la existencia de una relación positiva y significativa entre la duración de la relación íntima y la victimización por agresiones psicológica leves. Estos resultados apelan a la elaboración de respuestas específicas de apoyo a los diferentes tipos de víctimas, así como a una apuesta en el desarrollo e implementación de medidas preventivas más adecuadas a las diferentes realidades.

Palabras clave: Violencia, relaciones intimas, parejas homosexuales, prevalencia

Violence in intimate relationships is a serious problem and is considered a matter of public health. Indeed, the literature shows that this form of violence in intimate relationships can result in high costs for the health of the victim, leading, for example, to a greater propensity for the development of chronic pain and the development of many psychological problems such as depression and anxiety (Carvalho, Lewis, Derlega, Winstead, \& Viggiano, 2011; Little \& Terrance, 2010). The investigation of intimate partner violence began in the 1970s as a result of the social recognition of violence in intimate relationships, including violence against women in the family (Jasinski \& Williams, 1998). Traditionally, research in this area focuses mainly on heterosexual relationships in which the woman tends to be identified as the main victim and the man as the aggressor (Richards, Noret, \& Rivers, 2003). This idea of women as victims and men as violence perpetrators is reflected in the lower level of exploration and investigation into violence by an intimate partner in other types of relationships such as same-sex relationships (Cezario, Fonseca Lopes, \& Lawrence, 2015; Finneran \& Stephenson, 2012; Santos, 2012). Despite of the fact that a large proportion of the violence in relationships involves heterosexual partners, several studies (e.g., Banks \& Fedewa, 2012; National Coalition of Anti-Violence Programs Project, 2013; Finneran \& Stephenson, 2012) have recognized that violence is also problematic in homosexual relationships, countering the typical characterization of these relationships as egalitarian and free from intimate violence (Ali \& Machado, 2005). Thus, studies in this area have revealed common features in the forms of violence present both in same-sex and heterosexual relationships and have found that physical, psychological and sexual abuse occur in both types of relationships (Antunes \& Machado, 2005; Cezario et al., 2015; Finneran \& Stephenson, 2012).

A study conducted in a US community of young GLB (gay, lesbian and bisexual) individuals by Freedner, Freed, Yang and Austin (2002), involving 521 participants, has found that $41.5 \%$ of gay men and $37.1 \%$ of lesbians had reported at least one incident of violence in their relationships. Following this research, a study conducted in the same country with 117 homosexual teenagers indicates that $1 / 4$ of the participants had experienced some type of violence by his/her partner and that one in ten had reported the existence of physical victimization, demonstrating that intimate violence is a significant problem 
for people engaged in same-sex teen relationships (Halpern, Young, Waller Martin, \& Kupper, 2004). Another research study conducted by Carvalho and colleagues (2011) with a US sample of 581 gay people of both sexes found that $24.2 \%$ of the participants were victims of violence in their intimate relationships and that $8.3 \%$ of the study participants reported the adoption of violent behaviour in their intimate relationships.

More recently, in another study conducted in China with a sample of 418 gay men and 330 heterosexual men, Yu, Xiao and Liu (2013) sought to compare the incidence of violence in intimate relationships among these two groups in the following five areas: Feeling in control, emotional abuse, fear for their safety, and physical and sexual violence. In the study, $32.8 \%$ of the gay men and $8.8 \%$ of the heterosexual participants revealed that they had experienced at least one of the five types of abuse. In addition, 82 gay men $(9.6 \%)$ reported that their partners tried to control their daily activities, including where they were going and with whom they spoke, and $11.2 \%$ of the gay participants reported that they had been insulted and humiliated in the presence of other people. Of the gay participants, $12.7 \%$ said that they feared for their safety in the face of threats from their partners, and $7.9 \%$ admitted that they had suffered physical violence. Those individuals who reported the existence of abusive experiences, $83.9 \%$ of gay men and $20.7 \%$ of heterosexual men, said they had never revealed those experiences to anyone.

Another recent study was conducted by Edwards and Sylaska (2013) with American college students who maintained loving relationships with same-sex partners. In a sample of 391 participants, physical violence emerged as the most reported (19.9\%) type of violence, followed by psychological abuse (12.5\%) and sexual abuse $(10.5 \%)$ from their partners. This sample also showed that approximately $1 / 3$ of the participants reported perpetrating any form of violence in their relationships, and $22.3 \%$ said that violence was bilateral.

A review of the international research in this area shows that there is a greater investment in the Americas in the study of intimate partner violence between persons of the same-sex (cf. Cezario et al., 2015). The knowledge of the extent and implications of this phenomenon show us the importance of extend this investigation to other countries, including Portugal, given the negligible research investment in this area.

Despite the shortage of Portuguese research on same-sex intimate partner violence, we found two studies that characterized the prevalence of this problem in the Portuguese gay community (Antunes \& Machado., 2005; Costa, Machado, $\&$ Antunes, 2011). A study of violence between same-sex partners developed by Antunes and Machado (2005), which involved 63 homosexual participants of both sexes, found that $20.6 \%$ of the participants had been victims of violence in their current relationship and that $15.9 \%$ had adopted violent behaviour with his/her partners. In terms of previous relationships, $61.9 \%$ of the sample reported that their partner adopted abusive behaviour, while $46 \%$ admitted using violence against his/her companion (Antunes \& Machado, 2005). Similarly, Costa and his colleagues (2011) studied a sample of 151 homosexual participants of both sexes aged between 15 and 60 years and asked about the year preceding the study; the study found that $35.1 \%$ of the respondents had been the victim of emotional violence, $24.5 \%$ admitted having been subjected to physical violence by a partner and $3.3 \%$ revealed that they had suffered from sexual violence by a partner. Regarding the adoption of abusive behaviour, $30.5 \%$ of the sample admitted to having committed at least one act of emotional violence against his/her partner, $24.5 \%$ reported being physically violent with his/her partner and $0.7 \%$ admitted to having committed at least one act of sexual violence against their partner.

Despite the lower level of scientific investment in the study of violence in intimate relationships in the gay population, the evidence proves that this is a problem that can no longer be ignored. The existence of an undetermined number of gay people worldwide and the fact that homosexuals and their respective relationships are often still closeted (Ali \& Machado, 2005) creates challenges in determining the exact scope of 
this phenomena (Little \& Terrance, 2010; Yu et al., 2013), which might have a greater reach and affect more people than what these studies have demonstrated.

This quantitative study intends to contribute to the depth of the knowledge regarding samesex intimate partner violence in the Portuguese context. In this sense, this study intended to collect data on the prevalence of different abusive behaviours that occurred in relationships between individuals of the same sex during the past year. More specifically, it was intended: to determine the prevalence of victimization and perpetration of different forms (psychological, physical and sexual) of intimate violence and to identify sociodemographic factors (e.g., gender) and relationship factors (e.g., type of intimate relationship, intimate relationship duration) associated with different types of abuse (in terms of victimization and aggression).

\section{Method}

\section{Participants}

As we can observe in Table 1, the final sample comprised 168 participants, of which 128 $(76.2 \%)$ were female and $40(23.8 \%)$ were male, who were between 18 and 35 years of age $(M=$ 22,$50 ; S D=3.79$ ).

Regarding qualifications, $48.2 \%$ of the participants had a 10th-12th grade education level, and $7.1 \%$ had a 7 th-9th grade education level. In addition, $30.4 \%$ had a college degree, $13.7 \%$ had completed second-cycle academic studies (master's degree), and only $0.6 \%$ of the participants had a $\mathrm{PhD}$. More than half of the participants $(56 \%)$ reported being a student, $26.2 \%$ were employed and $17.9 \%$ were unemployed.

A small proportion of the sample $(0.6 \%)$ reported having had a homosexual intimate relationship in the past year and were in a heterosexual relationship at the time of the study. More than half (60.1\%) were currently in a relationship. Most of the participants were single $(92.9 \%), 6.5 \%$ were married/living together and $0.6 \%$ were divorced/separated (cf. Table 2 ). Regarding the most recent same-sex relationship that had occurred in the past year, it was found that $89.9 \%$ had a sexual component and $71.4 \%$ did not involve cohabitation. In terms of the duration of the most recent intimate relationship with an individual of the same sex, $31 \%$ lasted 2 years or more, $12.9 \%$ lasted between 1 to 2 years, $7.7 \%$ were approximately 1 year, $10.7 \%$ were between 6 and 11 months, 14.3\% lasted 3 to 5 months, $4.2 \%$ lasted approximately 2 months, and $1.8 \%$ were approximately 1 month to less than 1 month.

\section{Instruments}

The instruments used in this study were the Revised Conflict Tactics Scales (CTS-2 Strauss, translated in 1979 and validated for the Portuguese context by Paiva \& Figueiredo, 2006) and a sociodemographic questionnaire developed to characterize the sample.

The CTS-2 is a translated and validated instrument for the Portuguese population that evaluates different adopted conflict resolution tactics (e.g., negotiation) and, more specifically, determines the prevalence of different forms of abuse (physical assault without sequelae, physical assault with sequelae, psychological aggression and sexual coercion) and its severity levels in the family context (minor or severe). This is a self-administered scale consisting of 39 items that are grouped in pairs of questions for both of the individuals in a relationship - the respondent and his/her partner. The CTS-2 has a total of 79 questions divided into five subscales, and the average time of administration is less than 15 minutes. Thus, negotiation is evaluated by 12 items (e.g., "I suggested an agreement to resolve a disagreement"), psychological aggression by 16 items (e.g., "Shouted or yelled at my partner"), physical abuse without sequelae by 24 items (e.g., minor, " Slapped my partner," severe, " Kicked my partner"), sexual coercion by 14 items [e.g., minor, "Insisted on sex when my partner did not want to (but did not use physical force)," severe, "Used force (like hitting, holding down, or using a weapon) to make my partner have sex"], and physical abuse with sequelae is evaluated by 12 items (e.g., minor, "I felt a physical pain, which remained the next day because of a fight with my partner," severe, "I fainted 
Table 1

Sociodemographic Characterization of the Participants

\begin{tabular}{lccc}
\hline & & Relative frequency $(\%)$ & Absolute frequency $(n)$ \\
\hline Gender & Male & 23.8 & 40 \\
& Female & 76.2 & 128 \\
Qualifications & 7th-9th grade & 7.1 & 12 \\
& 10th-12th grade & 48.2 & 51 \\
Graduation & 30.4 & 23 \\
Master's degree & Phd & 13.7 & 1 \\
Professional & Unemployed & 0.6 & 30 \\
situation & Student & 17.9 & 94 \\
Employed & 56 & 44
\end{tabular}

Table 2

The Last Intimate Relationship Characterization with Same-Sex Partners

Relative frequency Absolute frequency

$(\%)$

$(n)$

\begin{tabular}{|c|c|c|c|}
\hline \multirow[t]{2}{*}{ Current Relational State } & Currently in a loving relationship & 60.1 & 101 \\
\hline & $\begin{array}{l}\text { Currently, I have no love affair, } \\
\text { but I have had in the past }\end{array}$ & 39.9 & 67 \\
\hline \multirow{8}{*}{$\begin{array}{l}\text { Duration of last same-sex } \\
\text { relationship }\end{array}$} & Less than a month & 1.8 & 3 \\
\hline & About 1 month & 1.8 & 3 \\
\hline & About 2 months & 4.2 & 7 \\
\hline & 3-5 months & 14.3 & 24 \\
\hline & 6-11 months & 10.7 & 18 \\
\hline & About a year & 7.7 & 13 \\
\hline & More than 1 and less than 2 years & 17.9 & 30 \\
\hline & 2 or more years & 31.0 & 52 \\
\hline \multirow{2}{*}{$\begin{array}{l}\text { Type of same-sex } \\
\text { relationship }\end{array}$} & Cohabitant & 28.0 & 47 \\
\hline & Not cohabitant & 71.4 & 120 \\
\hline \multirow{2}{*}{$\begin{array}{l}\text { The intimate relationship } \\
\text { has / had a sexual component }\end{array}$} & Yes & 89.9 & 151 \\
\hline & No & 3.6 & 6 \\
\hline
\end{tabular}


because my partner hit me in the head during a fight"). We chose this instrument because it enabled us to obtain data on both individuals in a relationship and determine the conflict resolution tactics adopted by each one during the past year, even if the questionnaire was answered by only one member of the couple. The instrument allowed us to count the number of occurrences in eight response categories - the first six determine prevalence and chronicity [(1) once in the previous year, (2) twice in the previous year (3) 3-5 times in the previous year, (4) 6-10 times in the previous year, (5) 11-20 times in the previous year, (6) more than 20 times last year] - and the remaining two determine overall prevalence: [(7) not in the previous year, but it occurred earlier] and the absence of this type of abuse [(8) never happened].

As this instrument evaluates different tactics for conflict resolution for particular forms of abuse, it is possible to determine overall prevalence, prevalence in the past year, annual frequency and chronicity. For this study, we evaluated overall prevalence by re-categorizing all the responses for categories 1-7 to the value 1 (occurred at some point) and the responses for category 8 to the value 0 (never happened).

\section{Procedures}

A request was submitted to the authors responsible for validation of the CTS-2 in the Portuguese context for authorization to use the CTS-2 in this study. Following this request, we proceeded with the preparation of the appropriate research protocol, including the description of the objectives of the study, the method used (self-report instrument - CTS-2) and informed consent, which was subsequently submitted to for review and validation by the Ethics Committee of the University in which the study was proposed.

At a later stage, and after obtaining the relevant authorizations to begin the study, the CTS2 , the sociodemographic questionnaire and the informed consent form for the participants were published in digital format on an online platform - Google Docs - so they could be completed online. We also requested the collaboration of sev- eral LGBT (lesbian, gay, bisexual, and transgender) associations to disseminate the study's link to their target population - the LGBT community - to recruit potential participants for the study. In addition, we asked students' associations to disseminate information through their mailing lists, and we distributed study information through the researchers' e-mail contacts (snowball technique), forums and social networks. The data collection took place between May and September 2014 using the online questionnaires, which were available only during this period. In the first portion of the questionnaire, the participants were presented with an informational section on the study objectives, criteria for inclusion in the sample, guarantees of the confidentiality and anonymity of the data provided and a record of the study's compliance with all ethical procedures and ethics. Following the instrument's completion, information was available on violence in intimate relationships between persons of the same sex, specifically the existence of support for victims and contact information for organizations offering support in case a participant wanted additional information or needed any type of support. When the data collection was completed, the data were transferred to a database built for this purpose using the computer program Statistical Package for Social Sciences (SPSS version 22.0) to begin the statistical data processing and the analysis of results.

Regarding the responses, we must note that we considered only those questionnaires that met the inclusion criteria, and these represented the final sample.

\section{Data Analysis}

The data collected in this study were subjected to statistical analysis using the SPSS software program version 22.0.

Although the specific tests performed are described as the results are presented, we will provide a brief overview of the adopted analytical strategy. Initially, descriptive analyses were carried out to characterize the sample and to estimate the prevalence of different forms of intimate abuse measured by the CTS-2. Next, we performed an inferential analysis using non- 
parametric tests among some of the sociodemographic data and the CTS-2; specifically, we used the Mann-Whitney test to analyse the relationship between abusive behaviour and the sex of the participants, including abusive behaviour and the type of intimate relationship (intimate relationship with or without cohabitation), and Spearman correlation coefficients to analyse the relationship between the duration of the relationship and the prevalence of abusive behaviour. We used SPSS to calculate the common language effect sizes for the Mann-Whitney test, following formula LC-TDE $=\mathrm{U} / \mathrm{mn}$, where $\mathrm{U}$ is the statistical Mann-Whitney, $m$ is the number of participants in the first sample, and $\mathrm{n}$ is the number of people in the second sample (Spirit Santo \& Daniel, 2015). Non-parametric tests were used because after the evaluation of normal distributions, it was found that these did not meet the assumptions that provide for statistical rigor in parametric tests.

\section{Results}

\section{Prevalence of Abusive Behaviour Perpetrated and Suffered}

Of the participants who reported having an intimate relationship with a same-sex partner, $92.3 \%$ reported the occurrence of at least one violent behaviour in their intimate relationship in the past year. Specifically, $91.7 \%$ of the sample reported having been victims of at least one abusive act during the last year, and $92.3 \%$ admitted the adoption of this type of conduct in relation to his/her partner during the same period.

For the different types of violence analysed by the CTS-2, the tables illustrate that in terms of victimization, there is a preponderance of psychological abuse: victimization by minor psychological aggression was reported by $69.2 \%$ of the participants, and victimization by severe psychological aggression was reported by $30.4 \%$. Sexual coercion appears to be the least reported type of violence: minor sexual coercion was reported by $29.2 \%$ of the sample, whereas severe sexual coercion was reported by $3.6 \%$. In relation to victimization, it was found that physically abusive behaviours that leave no sequelae are slightly higher than those leaving sequelae. Physical abuse without minor sequelae was reported by $28.6 \%$ of the sample and physical abuse without severe sequelae was reported by $11.9 \%$, whereas abuse with minor and severe sequelae was reported by $10.7 \%$ and $1.2 \%$ of the participants, respectively.

In terms of perpetration, and similar to the findings for victimization, the participants reported higher rates of psychological aggression than physical abuse or sexual coercion. Thus, $70.2 \%$ of the participants admitted having practiced minor psychological aggression, and $29.8 \%$ admitted engaging in severe psychological aggression. In terms of physically abusive behaviour, and similar to the findings for victimization, there was a slightly higher rate for acts that leave no sequelae than for those that do. Thus, the practice of minor physical abuse without sequelae was reported by $26.8 \%$ of the sample, and severe physical abuse without sequelae was reported by $9.5 \%$. The prevalence rate of minor and severe physical abuse was $11.3 \%$ and $1.8 \%$, respectively. Additionally, $28 \%$ of the participants admitted adopting behaviours that fall within the area of minor sexual coercion, and $1.2 \%$ admitted adopting behaviours that reflect severe sexual coercion.

Finally, given the prevalence of victimization and perpetration, it was possible to verify, through an analysis of Spearman correlations, the existence of statistically significant correlations between the different types of perpetrated abuse and victims, particularly with regard to perpetration and global victimization (rho $=$ $0.961, p=.001)$.

\section{Abusive Behaviour and Sex}

When using the Mann-Whitney test to compare abusive behaviour according to the sex of the participants, it was found that there are no statistically significant differences between the sexes. However, in terms of victimization, it was established that there are significant differences $[Z(U)=-3,311 ; p=.001]$ only for minor sexual coercion and that more men admitted suffering from this type of behaviour (see Table 3 ). 
In terms of perpetration, there were differences between the sexes for sexual coercion $[\mathrm{Z}$ $(U)=-2.740 ; p=.006]$. Thus, the perpetration of minor sexual coercion was higher among the male participants than the females. This significant disparity for sex was also detected in the perpetration of physical abuse with severe sequelae $[Z(U)=-3,117 ; p=.013]$ (see Table 3).

Table 3

Comparison by Sex, the Prevalence of Abusive Behavior

\begin{tabular}{|c|c|c|c|c|c|c|c|}
\hline & \multirow[t]{2}{*}{ Types of abuse } & \multicolumn{2}{|c|}{ Male } & \multicolumn{2}{|c|}{ Female } & \multirow[t]{2}{*}{$\mathrm{Z}(U)$} & \multirow[t]{2}{*}{ TDE-LC } \\
\hline & & $n$ & $\begin{array}{c}\text { Average } \\
\text { order }\end{array}$ & $n$ & 0.49 & & \\
\hline \multirow{9}{*}{ 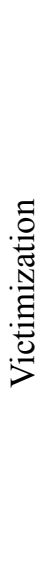 } & Global & 40 & 85.20 & 128 & 0.49 & -0.218 & 0.49 \\
\hline & Minor physical assault without sequelae & 39 & 85.69 & 128 & 0.49 & -0.318 & 0.49 \\
\hline & Severe physical assault without sequelae & 40 & 82.90 & 128 & 0.49 & -0.425 & 0.49 \\
\hline & Minor physical assault with sequelae & 40 & 83.35 & 127 & 0.48 & -0.182 & 0.49 \\
\hline & Severe physical assault with sequelae & 40 & 87.70 & 128 & 0.46 & -2.537 & 0.48 \\
\hline & Minor psychological aggression & 38 & 76.29 & 124 & 0.48 & -1.009 & 0.46 \\
\hline & Severe psychological aggression & 39 & 86.33 & 128 & 0.36 & -0.431 & 0.48 \\
\hline & Minor sexual coercion & 40 & 102.00 & 128 & 0.47 & $-3.311 * *$ & 0.36 \\
\hline & Severe sexual coercion & 40 & 87.80 & 128 & 0.50 & -1.529 & 0.47 \\
\hline \multirow{9}{*}{ 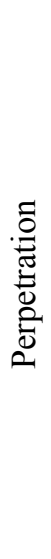 } & Global & 40 & 84.70 & 128 & 0.50 & -0.064 & 0.50 \\
\hline & Minor physical assault without sequelae & 40 & 85.10 & 128 & 0.48 & -0.117 & 0.50 \\
\hline & Severe physical assault without sequelae & 40 & 87.00 & 128 & 0.49 & -0.732 & 0.48 \\
\hline & Minor physical assault with sequelae & 39 & 83.06 & 128 & 0.46 & $-0,251$ & 0.49 \\
\hline & Severe physical assault with sequelae & 40 & 89.30 & 128 & 0.47 & $-3,117^{*}$ & 0.46 \\
\hline & Minor psychological aggression & 38 & 78.76 & 125 & 0.50 & -0.623 & 0.47 \\
\hline & Severe psychological aggression & 40 & 84.70 & 128 & 0.39 & -0.038 & 0.50 \\
\hline & Minor sexual coercion & 40 & 98.80 & 128 & 0.49 & $-2.740 * *$ & 0.39 \\
\hline & Severe sexual coercion & 40 & 85.60 & 128 & TDE-LC & -0.872 & 0.49 \\
\hline
\end{tabular}

${ }^{* *} p<.01 ; * p<.05 ;+$ partially significant.

\section{Abusive Behaviour and Type of Intimate Relationship}

Regarding the differences between the participants' type of intimate relationship, which were identified using the Mann-Whitney test, we can observe statistically significant differences in relation to victimization for severe physical abuse without sequelae $[Z(U)=-2,838 ; p$ $=.007]$, minor physical abuse with sequelae [Z $(U)=-2,156 ; p=.033]$ and minor psychological aggression $[\mathrm{Z}(U)=-3.735 ; p=.001]$, indicat- ing a higher rate of prevalence for these forms of abuse in cohabiting relationships than in noncohabiting relationships. This trend towards a higher prevalence among the cohabitating participants in comparison to the non-cohabiting participants is also found in the perpetration of abusive behaviour, particularly minor physical abuse without sequelae $[Z(U)=-2,063 ; p=$ $.032]$, severe physical abuse without sequelae [Z $(U)=-2.038 ; p=.044]$ and minor psychological aggression $[\mathrm{Z}(U)=-2.927 ; p=.002]$ (see Table 4). 
Table 4

Comparison by Type of Intimate Relationship, the Prevalence of Abusive Behavior

\begin{tabular}{|c|c|c|c|c|c|c|c|}
\hline \multicolumn{2}{|r|}{ Types of abuse } & \multicolumn{2}{|c|}{ Male } & \multicolumn{2}{|c|}{ Female } & \multirow[t]{2}{*}{$\mathrm{Z}(U)$} & \multirow[t]{2}{*}{ TDE-LC } \\
\hline & & $n$ & $\begin{array}{c}\text { Average } \\
\text { order }\end{array}$ & $n$ & $\begin{array}{c}\text { Average } \\
\text { order }\end{array}$ & & \\
\hline \multirow{9}{*}{ 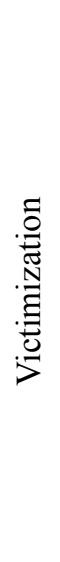 } & Global & 40 & 85.20 & 128 & 84.28 & -0.218 & 0.49 \\
\hline & Minor physical assault without sequelae & 39 & 85.69 & 128 & 83.48 & -0.318 & 0.49 \\
\hline & Severe physical assault without sequelae & 40 & 82.90 & 128 & 85.00 & -0.425 & 0.49 \\
\hline & Minor physical assault with sequelae & 40 & 83.35 & 127 & 84.20 & -0.182 & 0.49 \\
\hline & Severe physical assault with sequelae & 40 & 87.70 & 128 & 83.50 & -2.537 & 0.48 \\
\hline & Minor psychological aggression & 38 & 76.29 & 124 & 83.10 & -1.009 & 0.46 \\
\hline & Severe psychological aggression & 39 & 86.33 & 128 & 83.29 & -0.431 & 0.48 \\
\hline & Minor sexual coercion & 40 & 102.00 & 128 & 79.03 & $-3.311 * *$ & 0.36 \\
\hline & Severe sexual coercion & 40 & 87.80 & 128 & 83.47 & -1.529 & 0.47 \\
\hline \multirow{9}{*}{ 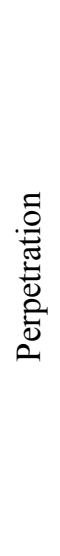 } & Global & 40 & 84.70 & 128 & 84.44 & -0.064 & 0.50 \\
\hline & Minor physical assault without sequelae & 40 & 85.10 & 128 & 84.31 & -0.117 & 0.50 \\
\hline & Severe physical assault without sequelae & 40 & 87.00 & 128 & 83.72 & -0.732 & 0.48 \\
\hline & Minor physical assault with sequelae & 39 & 83.06 & 128 & 84.25 & $-0,251$ & 0.49 \\
\hline & Severe physical assault with sequelae & 40 & 89.30 & 128 & 83.00 & $-3,117^{*}$ & 0.46 \\
\hline & Minor psychological aggression & 38 & 78.76 & 125 & 82.98 & -0.623 & 0.47 \\
\hline & Severe psychological aggression & 40 & 84.70 & 128 & 84.44 & -0.038 & 0.50 \\
\hline & Minor sexual coercion & 40 & 98.80 & 128 & 80.03 & $-2.740 * *$ & 0.39 \\
\hline & Severe sexual coercion & 40 & 85.60 & 128 & 84.16 & -0.872 & 0.49 \\
\hline
\end{tabular}

$* * * p<.001 ; * * p<.01 ; * p<.05$.

\section{Abusive Behaviour and Duration of the Relationship}

To analyse the relation between the duration of the relationship and the prevalence of abusive behaviour, we used the Spearman correlation coefficient (see Table 3). The results showed that only victimization by minor psychological aggression $(\mathrm{rho}=0.172, p=.040)$ and perpetration of minor physical abuse without sequelae (rho $=$ $0.218, p=.007)$ are significantly and positively related to the duration of the relationship, suggesting that the longer the intimate relationship is, the greater the likelihood of victimization by severe psychological aggression and/or the adoption of physically abusive and severe behaviours that leave sequelae.

\section{Discussion}

This study aims to assess the prevalence of abusive behaviour in same-sex intimate relationships and analyse its relationship with the sociodemographic characteristics of the participants. The results support the conclusions of several studies that focus on this issue, indicating that behaviours considered abusive are also found in this type of relationship (e.g., Antunes \& Machado, 2005; Burke, Jordan, \& Owen, 2002; Costa et al., 2011; Yu et al., 2013), thus raising questions about the prevalence of violence in relationships between same-sex partners.

Regarding the overall prevalence of violence, very high levels were found in terms of 
Table 5

Relation between the Duration of the Close Relationship and the Prevalence of Abusive Behavior

\begin{tabular}{|c|c|c|}
\hline & & Correlation Coefficient Spearman's rho \\
\hline \multirow{9}{*}{ 菾 } & Global & -0.016 \\
\hline & Minor physical assault without sequelae & 0.118 \\
\hline & Severe physical assault without sequelae & 0.104 \\
\hline & Minor physical assault with sequelae & 0.076 \\
\hline & Severe physical assault with sequelae & -0.109 \\
\hline & Minor psychological aggression & $0.172 *$ \\
\hline & Severe psychological aggression & 0.006 \\
\hline & Minor sexual coercion & 0.024 \\
\hline & Severe sexual coercion & -0.040 \\
\hline \multirow{9}{*}{ 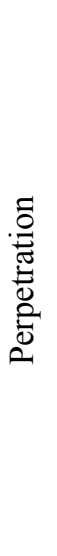 } & Global & 0.013 \\
\hline & Minor physical assault without sequelae & $0.218^{* *}$ \\
\hline & Severe physical assault without sequelae & 0.046 \\
\hline & Minor physical assault with sequelae & 0.135 \\
\hline & Severe physical assault with sequelae & -0.058 \\
\hline & Minor psychological aggression & 0.136 \\
\hline & Severe psychological aggression & -0.054 \\
\hline & Minor sexual coercion & 0.051 \\
\hline & Severe sexual coercion & -0.008 \\
\hline
\end{tabular}

${ }^{*} p<.05 ; * * p<.01$.

both perpetration $(92.3 \%)$ and victimization $(91.7 \%)$. In the present study, the prevalence rates of the different types of abusive behaviour are significantly higher than those of other studies, which found rates ranging between $7.6 \%$ and 57.7\% (Finneran \& Stephenson, 2013; Frankland \& Brown, 2014; Milletich, Gumienny, Kelley, \& D’Lima, 2014; Pantalone, Schneider Valentine \& Simoni, 2012; Yu et al., 2013). Nevertheless, the results of our study are similar to the study conducted by Turell and Cornell-Swanson (2005), which also found a high prevalence rate of $89 \%$.

Comparing our data with the evidence collected by other investigations in the Portuguese context, we can also recognize that the abuse rates we found are clearly higher than the abuse indexes calculated in the study by Antunes and Machado (2005), in which $20.6 \%$ of the par- ticipants reported that they were the victim of at least one abusive act and $15.9 \%$ admitted the perpetration of any violent behaviour, and higher than those reported later in the study by Costa et al. (2011), which detected an intimate violence perpetration rate of $39.1 \%$ and a victimization rate of $37.7 \%$.

Concomitantly, the tabulation of positive correlations and significant statistics for overall perpetration and victimization in this study leads us to the theory of bi-directionality of violence, which is frequently supported by studies of this nature (Costa et al., 2011; Oringher \& Samuelshon, 2011). However, it is imperative to note that although these values are disturbing, both for global prevalence and the various more specific forms of violence, the evaluation focused on the occurrence of different abusive acts at least once during the past year. Thus, con- 
sidering the limitations of this study, the results should be interpreted cautiously.

The abusive behaviours more commonly reported by the participants are psychological aggression, in both the minor and severe form, in terms of victimization $(69.6 \%$ vs $30.4 \%)$ and perpetration $(70.2 \%$ vs $29.8 \%)$. These data corroborate what has been observed in other national and international studies (Antunes \& Machado, 2005; Costa et al., 2011; Finneran \& Stephenson, 2013; Matte \& Lafontaine, 2011; Pantalone et al., 2012; Turell, 2000; Yu et al., 2013). However, other studies (Blosnich \& Bossarte, 2009; Edwards \& Sylaska, 2013; Halpern et al., 2004; Ramachandran, Yonas, Silvestre, \& Burke, 2010) show that physical violence is the most frequent. However, with regard to the prevalence rate of this form of violence, this study found higher values than have been found in most prior studies, proving to be consistent with two studies carried out with the same instrument (Craft \& Serovich, 2005; Matte \& Lafontaine, 2011) and three with an unspecified self-report questionnaire (Blosnich \& Bossarte, 2009; Donovan, Hester, Holmes, \& McCarry, 2006; Turell, 2000). These results primarily highlight the high and alarming rates of psychological aggression in intimate relationships, not just the most frequently occurring form of violence in them. Thus, on the one hand, a question arises regarding the instrument(s) used: perhaps the instrument is more sensitive to the recognition of abuse and therefore overestimates its occurrence or suggests that psychological violence has been adopted when a behaviour is a tactical and natural way of resolving conflicts in loving relationships (Bolze, Schmidt, Crepaldi, \& Vieira, 2013; Mosmann \& Falcke, 2011). On the other hand, given that abusive episodes tend to begin with behaviours that are "less violent" and that these behaviours may become "more violent" over time, psychological aggression is a predictor of other forms of violence (Antunes \& Machado, 2005) and the focus on physical violence may promote a microscopic and fragmented view of the phenomena of violence or devalue psychological aggression in relational contexts.
In this study, minor sexual coercion, for both victimization and perpetration, is found to be the most prevalent type of abuse following psychological aggression ( $28 \%$ vs $29.2 \%)$. This result was also found in other studies in which the rate of minor sexual coercion is between 9.6\% and 40.5\% (Donovan et al., 2006; Toro-Alfonso, 1999; Toro-Alfonso \& Rodríguez-Madera, 2004b; Yu et al., 2013). Further investigation (Blosnich \& Bossarte, 2009; Craft \& Serovich., 2005; Ramachandran et al., 2010) showed relatively similar values: between $27.5 \%$ and $33 \%$. However, this trend among the participants of readily reporting psychological aggression and sexual coercion should be carefully analysed as this may be associated with a certain cultural bias. Because these may be perceived as behaviours that tend to be socially accepted, admitting to these behaviours may be perceived as a way to assume a lower level of culpability than admitting to physical violence, which tends to be more stigmatized from a social point of view (Paiva \& Figueiredo, 2005).

Regarding the prevalence of physical abuse found in this study, it appears that there are higher rates for the forms that do not leave sequelae than for those that do. According to the findings from the study, $26.8 \%$ of the participants admitted to the perpetration of minor physical abuse without sequelae and $9.5 \%$ admitted to the perpetration of severe physical abuse without sequelae, whereas $11.3 \%$ reported perpetrating minor physical abuse with sequelae and $1.8 \%$ reported perpetrating severe physical abuse. In relation to victimization, $28.6 \%$ of the participants reported the occurrence of minor physical abuse without sequelae, $11.9 \%$ reported severe physical abuse without sequelae, $10.7 \%$ reported minor physical abuse with sequelae and 1.2\% reported severe physical abuse with sequelae. Although the studies developed in this area generally do not seek to distinguish between physical abuse with sequelae and physical abuse without sequelae, it is possible to see similarities in their prevalence rates, which range between $7.9 \%$ and $31 \%$ (Antunes \& Machado 2005; Costa et al., 2009; Edwards \& Sylaska, 2013; Finneran \& Stephenson, 2013; Halper et al., 2004; Houston \& McKirnan, 
2007; Matte \& Lafontaine, 2011; Pantalone et al., 2012; Ramachandran et al., 2010; Turell, 2000; Yu et al., 2013), as well as differences, as the rates found in this study are lower than the results of other studies that report rates between 45.1\% and 89.9\% (Blosnich \& Bossarte, 2009; Craft \& Serovich, 2005; Greenwood et al., 2002). Again, the social stigma of domestic violence may contribute to explaining the lower volume of reports of this type of abuse by participants (Paiva \& Figueiredo, 2005). Nevertheless, it is imperative to note that the vast distribution of prevalence rates documented in different studies of intimate abuse among same-sex partners has been commonly associated with methodological problems (Donovan et al., 2006;. Murray, Mobley, Buford, \& Seaman-DeJohn, 2006/2007). In particular, these methodological problems are related to the characteristics of the studies' samples (Buller, Devries, Howard, \& Bacchus, 2014; Burke \& Follingstad, 1999; Rohrbaugh, 2006; Tjaden \& Thoennes, 2000) and the nature of the measure, the type of instruments, and the definition of intimate abuse (Buller et al., 2014) used in the studies. Thus, the values found in this study may result from specific aspects of the sample itself.

Regarding gender differences, we found statistically significant differences only for the perpetration of sexual coercion, both in minor and severe form, suggesting that the male participants adopt this type of behaviour more than the female participants, although participants of both sexes admitted to being the perpetrators and victims of these behaviours. Although there are no similar conclusions in previous research on violence in intimate relationships between samesex partners, particularly with regards to sexual coercion, we can verify that men tend to be more associated than women with the use of physical aggression in the resolution of their interpersonal conflicts (Antunes \& Machado, 2005).

Regarding differences in the type of relationship, we were able to find statistically significant differences only for victimization in terms of physical abuse without severe consequences, minor physical abuse with sequelae and psychological abuse, minor physical abuse without sequelae, and severe physical abuse without sequelae and only for perpetration in terms of psychological abuse; these types of violence were more prevalent in relationships in which the partners were cohabiting. The literature reveals that the occurrence of abusive acts tends to be more likely in relationships in which there is cohabitation (Bolze et al., 2013; \& Falcke Mosmann, 2011), which may be related to the higher level of commitment and relational involvement.

Having observed the duration of the relationship, we found that it is positively and significantly correlated only with victimization by minor psychological aggression and the perpetration of minor physical abuse without sequelae. In this sense, the greater the length of the relationship is, the greater the likelihood of such violence. Indeed, research on intimate relationships has shown the existence of an escalation of violence during the course of the relationship (Antunes \& Machado, 2005; Mahoney, Williams, \& West, 2001), so it is imperative not to belittle any abusive act in relationships.

\section{Conclusion}

By focusing on violence in intimate relationships between same-sex partners, this study contributed to the knowledge regarding a reality that has been largely ignored by the scientific community - which has focused more on heterosexual intimate relationships - by demonstrating that it is imperative to avoid restricting the study of this field to so-called traditional relationships (Antunes \& Machado, 2005). More specifically, and concerning the Portuguese context, this study reveals what the few national studies have shown (see Antunes \& Machado, 2005; Costa et al., 2011): the existence of the phenomena of violence in intimate relationships between people the same sex, allowing us to present more comprehensive results than had been previously found, such as evidence of the bi-directionality of violence. Thus, the high prevalence rates calculated in this study reiterate the urgent need to give greater visibility to this phenomenon, which is characterized socially by its "double invisibility" (Antunes \& Machado, 2005, p. 167). This 
may be because same-sex couples are faced with the additional fear of discrimination manifested largely through homophobia and the condemnation of homosexuality, which in turn fosters secrecy in situations of violence. However, this imperative need to deepen our knowledge allows us to respond to individuals involved in abusive relationships not only through the development of mechanisms (in)formal support for different types of victims (e.g., the creation of shelters for women victims of violence by an intimate partner of the same sex, avoiding offender-victim meetings, and support for the men themselves) but also through prevention via the development and implementation of prevention efforts that are adapted for the situation in question.

On the one hand, this study, due to its quantitative nature, does not explore issues related to the underlying motivations for abusive experiences and the adoption of these abusive behaviours (e.g., self-defence), the context of the abuse's initiation, the interactive sequence of abusive experience or the meaning attributed to the abuse by those involved. On the other hand, this study does not assess the frequency of abusive acts, and because abusive acts are represented by only one occurrence, their evolution is not demonstrated (e.g., escalation of violence). It should be noted that due to difficulty encountered in accessing the population that maintains close homosexual relationships, the study sample is small and is mainly composed of female participants. As with other studies in this area, this research involves a convenience sample that is not representative; thus, these results cannot be generalized to the Portuguese population. The instrument uses validated scales for heterosexual samples, which could influence factual reporting by same-sex subjects and result in inaccurate measurements of the phenomenon in relationships between people of the same sex (Buller et al., 2014). In this sense, further research is urgently needed, of both a quantitative nature and qualitative nature, on violence in intimate relationships between individuals of the same sex that preferably includes larger and more representative samples of this population, particularly in Portugal. Thus, the assessment of prevalence rates in this population is imperative in order to address the above-mentioned limitations and to gain a better understanding of the meanings, motivations, backgrounds and interactive sequences inherent in this phenomenon from both the perpetration and victimization perspectives.

\section{References}

Antunes, R., \& Machado, C. (2005). Dupla invisibilidade: A violência nas relações homossexuais. Psychologica, 39, 167-187.

Banks, J. R., \& Fedewa, A. L. (2012). Counselors' attitudes toward domestic violence in same-sex versus opposite-sex relationships. Journal of Multicultural Counseling and Development, 40, 194-205. doi:10.1002/j.21611912.2012.00017.x

Bolze, S. D. A., Schmidt, B., Crepaldi, M. A., \& Vieira, M. L. (2013). Relacionamento conjugal e táticas de resolução de conflito entre casais. Actualidades en Psicología, 27(114), 71-85.

Blosnich, J. R., \& Bossarte, R. M. (2009). Comparisons of intimate partner violence among partners in same-sex and opposite-sex relationships in the United States. American Journal of Public Health, 99(12), 2182-2184. doi:10.2105/ AJPH.2008.139535

Buller, A. M., Devries, K. M., Howard, L. M., \& Bacchus, L. J. (2014) Associations between intimate partner violence and health among men who have sex with men: A systematic review and meta-analysis. PLoS Med 11(3), e1001609. doi:https://doi.org/10.1371/journal. pmed.1001609

Burke, L. K., \& Follingstad, D. R. (1999). Violence in lesbian and gay relationships: Theory, prevalence, and correlational factors. Clinical Psychology Review, 19(5), 487-512.

Burke, T. W., Jordan, M. L., \& Owen, S. S. (2002). A cross-national comparison of gay and lesbian domestic violence. Journal of Contemporary Criminal Justice, 18(3), 231-257.

Carvalho, A. F., Lewis, R. J., Derlega, V. J., Winstead, B. A., \& Viggiano, C. (2011). Internalized sexual minority stressors and same-sex intimate partner violence. Journal of Family Violence, 26, 501-509.

Cezario, A. C. F., Fonseca, D. S., Lopes, N. C., \& Lourenço, L. M. (2015). Violência entre par- 
ceiros íntimos: Uma comparação dos índices em relacionamentos hetero e homossexuais. Temas em Psicologia, 23(3), 565-575. doi:10.9788/ TP2015.3-04

Costa, L. G., Machado, C., \& Antunes, R. (2011). Violência nas relações homossexuais: A face oculta da agressão na intimidade. Psychologica, 1, 2-15.

Craft, S. M., \& Serovich, J. M. (2005). Family-of-origin factors and partner violence in the intimate relationships of gay men who are HIV positive. Journal of Interpersonal Violence, 20(7), 777 791. doi:10.1177/0886260505277101

Donovan, C., Hester, M., Holmes, J., \& McCarry, M. (2006). Comparing domestic abuse in same sex and heterosexual relationships. Retrieved from http://www.bris.ac.uk/sps/research/projects/ completed/2006/rc1307/rc1307finalreport.pdf

Edwards, K. M., \& Sylaska, K. M. (2013). The perpetration of intimate partner violence among LGBTQ college youth: The role of minority stress. Journal of Youth and Adolescence, 42, 17211731. doi:10.1007/s10964-012-9880-6

Espírito-Santo, H., \& Daniel, F. (2015). Calcular e apresentar tamanhos do efeito em trabalhos científicos (1): As limitações do $p<0,05$ na análise de diferenças de médias de dois grupos. Revista Portuguesa de Investigação Comportamental e Social, 1(1), 3-16.

Finneran, C., \& Stephenson, R. (2012). Intimate partner violence among men who have sex with men: A systematic review. Trauma, Violence, \& Abuse, 14(2), 168185. doi:10.1177/1524838012470034

Finneran, C., \& Stephenson, R. (2013). Gay and bisexual men's perceptions of police helpfulness in response to male-male intimate partner violence. Western Journal of Emergency Medicine, 14(4), 354-362. doi:10.5811/westjem.2013.3.15639

Frankland, A., \& Brown, J. (2014). Coercive control in same-sex intimate partner violence. Journal of Family Violence, 29, 15-22.

Freedner, N., Freed, L. H., Yang, Y. W., \& Austin, S. B. (2002). Dating violence among gay, lesbian, and bisexual adolescents: Results from a community survey. Journal of Adolescent Health, 31, 469-474. doi:http://dx.doi.org/10.1016/ S1054-139X(02)00407-X

Greenwood, G. L., Relf, M. V., Huang, B., Pollack, L. M., Canchola, J. A., \& Catania, J. A. (2002).
Battering victimization among a probabilitybased sample of men who have sex with men. American Journal of Public Health, 92(12), 1964-1969. Retrieved from http://www.ncbi. nlm.nih.gov/pmc/articles/PMC1447360/.

Halpern, C. T., Young, M. L., Waller, M. W., Martin, S. L., \& Kupper, L. L. (2004). Prevalence of partner violence in same-sex romantic and sexual relationships in a national sample of adolescents. Journal of Adolescent Health, 35, 124131.

Houston, E., \& McKirnan, D. J. (2007). Intimate partner abuse among gay and bisexual men: Risk correlates and health outcomes. Journal of Urban Health: Bulletin of the New York Academy of Medicine, 84(5), 682-690.

Jasinski, J. L., \& Williams, L. M. (Eds.). (1998). Partner violence: A comprehensive review of twenty years of research. Thousand Oaks, CA: Sage.

Little, B., \& Terrance, C. (2010). Perceptions of domestic violence in lesbian relationships: Stereotypes and gender role expectations. Journal of Homosexuality, 57, 429-440. doi:10.1080/00918360903543170

Mahoney, P., Williams, L. M. \& West, C. M. (2001). Violence against women by intimate relationships partners. In C. M. Renzetti, J. L. Edleson, $\&$ R. K. Bergen (Eds.), Sourcebook on violence against women (143-178). Thousand Oaks, CA: Sage.

Matte, M., \& Lafontaine, M.F. (2011). Validation of a measure of psychological aggression in samesex couples: Descriptive data on perpetration and victimization and their association with physical violence. Journal of GLBT Family Studies, 7(3), 226-244. doi:10.1080/1550428X.2011.564944

Milletich, R. J., Gumienny, L. A., Kelley, M. L., \& D’Lima, G. M. (2014). Predictive factors for intimate partner violence against women. Journal of Family Violence, 29(6), 653-664. doi:10.1007/ s10896-014-9620-7

Mosmann, C., \& Falcke, D. (2011). Conflitos conjugais: Motivos e frequência. Revista SPAGESP, 12(2), 5-16. Retrieved from http://pepsic. bvsalud.org/pdf/rspagesp/v12n2/v12n2a02.pdf

Murray, C. E., Mobley, A. K., Buford, A. P., \& Seaman-DeJohn, M. M. (2006/2007). Samesex intimate partner violence: Dynamics, social context, and counseling implications. The Jour- 
nal of LGBT Issues in Counseling, 1(4), 7-30. Retrieved from https://libres.uncg.edu/ir/uncg/f/ AK_Mobley_Same_2007.pdf

National Coalition of Anti-Violence Programs Project. (2013). Lesbian, gay, bisexual, transgender, queer, and HIV-Affected intimate partner violence in 2012. A Report of the National Coalition of Anti-Violence Programs. New York: Author. Retrieved from http:// www.avp.org/storage/documents/ncavp_2012 ipvreport.final.pdf $\backslash n h t t p: / / w w w . a v p . o r g /$ storage/documents/ncavp_2012_hvreport_final. pdf

Oringher, J., \& Samuelshon, K. W. (2011). Intimate partner violence and the role of masculinity in male same-sex relationships. Traumatology, 17(2), 68-74. doi:10.1177/1534765610395620

Paiva, C., \& Figueiredo, B. (2005). Abuso no relacionamento íntimo e estado desaúde em jovens adultos portugueses.

Paiva, C., \& Figueiredo, B. (2006). Versão portuguesa das "Escalas de Táticas de Conflito Revisadas": Estudo de validação. Psicologia: Teoria e Prática, 8(2), 14-39. Retrieved from http://app. parlamento.pt/violenciadomestica/conteudo/ pdfs/biblioteca/paivacts2.pdf

Pantalone, D. W., Schneider, K. L., Valentine, S. E., \& Simoni, J. M. (2012). Investigating partner abuse among HIV-Positive men who have sex with men. AIDS and Behavior, 16, 1031-1043. doi:10.1007/s10461-011-0011-2

Ramachandran, S., Yonas, M. A, Silvestre, A. J., \& Burke, J. G. (2010). Intimate partner violence among HIV-positive persons in an urban clinic. AIDS Care, 22(12), 1536-1543. doi:10.1080/09 540121.2010 .482199

Richards, A., Noret, N., \& Rivers, I. (2003). Violence and abuse in same-sex relationships: A review of literature. Leeds: University of Leeds, York St. John College. Retrieved from http://mesmac. co.uk/uploads/cms/files/violence_and_abuse. pdf.
Rohrbaugh, J. B. (2006). Domestic violence in same-gender relationships. Family Court Review, 44(2), 287-299. doi:10.1111/j.17441617.2006.00086.x

Santos, A. C. (2012). Entre duas mulheres isso não acontece - Um estudo exploratório sobre violência conjugal lésbica. Revista Crítica de Ciências Sociais, 98, 3-24. Retrieved from https://rccs. revues.org/4988?lang=fr

Tjaden, P., \& Thoennes, N. (2000). Extent, nature, and consequences of intimate partner violence. Retrieved from https://www.ncjrs.gov/pdffiles1/ nij/181867.pdf.

Toro-Alfonso, J. (1999). Domestic violence among same sex partners in Puerto Rico. Journal of Gay \& Lesbian Social Services, 9(1), 69-78. doi:10.1300/J041v09n01 04

Toro-Alfonso, J., \& Rodríguez-Madera, S. (2004). Sexual coercion in a sample of Puerto Rican gay males. Journal of Gay \& Lesbian Social Services, 17(1), 47-58. doi:10.1300/J041v17n01 04

Turell, S. C. (2000). A descriptive analysis of samesex relationship violence for a diverse sample. Journal of Family Violence, 15(3), 281-293.

Turell, S. C., \& Cornell-Swanson, L. V. (2005). Not all alike. Journal of Gay \& Lesbian Social Services, 18(1), 71-88. doi:10.1300/J041v18n01_06

Yu, Y., Xiao, S., \& Liu, K. Q. (2013). Dating violence among gay men in China. Journal of Interpersonal Violence, 28(12), 2491-2504. doi: $10.1177 / 0886260513479028$
Recebido: 21/03/2016

$1^{a}$ revisão: $1 \% 07 / 2016$

$2^{a}$ revisão: $10 / 07 / 2016$ Aceite final: 14/07/2016 